\title{
Pendampingan dan Penguatan Kemampuan Guru dalam Penggunaan Media Pembelajaran secara Daring
}

\author{
Ari Hasan Ansori ${ }^{1}$ dan Nandang Kosim ${ }^{2}$ \\ $1^{\text {st }}$ STKIP Syekh Manshur dan cep.arie@gmail.com \\ $2^{\text {nd }}$ STAI Syekh Manshur dan nandangkosim14@gmail.com
}

2021 by the authors. Submitted for possible open access publication under the terms and conditions of the Creative Commons Attribution-ShareAlike 4.0 International License-(CC-BY-SA) (https://creativecommons.org/licenses/by-sa/4.0/)

DOI : http://dx.doi.org/10.30983/dedikasia.vli2.5044

\begin{tabular}{ll}
\hline ARTICLE INFO \\
\hline Submit $: 07$ September 2021 \\
Revised $: 01$ Desember 2021 \\
Accepted $: 30$ Desember 2021
\end{tabular}

Keywords:

Kompetensi guru; media pembelajaran daring.

International License-(CC-BY-SA)

\section{ABSTRACT}

Dampak Pandemi Covid-19 telah mempengaruhi segala aspek tatanan kehidupan manusia, tidak hanya sebatas aspek kesehatan saja tanpa kecuali termasuk berdampak pada aspek pendidikan. Pemerintah melakukan pembatasan kegiatan pembelajaran untuk menghindari penyebaran covid-19 melalui pembelajaran secara daring. Terdapat banyak media pembelajaran daring yang dapat digunakan seperti Zoom Meeting, WhatsApp, Google Classroom, Google Meeting, Edmodo dan lainnya. Akan tetapi, pendidik guru harus cerdas dan kreatif dalam memilih media pembelajaran yang sesuai. Maka pendampingan dan penguatan kemampuan guru dalam penggunaan media sangat penting dan mendesak untuk dilakukan. Metode yang digunakan dalam pengabdian masyarakat ini adalah metode pengabdian berbasis Service learning. Pengabdian masyarakat yang dilakukan dengan melakukan bimbingan, pelatihan dan pendampingan bagi guru dalam penggunaan media pembelajaran dengan bijak dan cermat. Setelah kegiatan pengabdian dilakukan, dilakukan juga evaluasi terhadap kegiatan bimbingan dan pendampingan penggunaan media dalam pembelajaran bagi guru untuk mengetahui dampak dari kegiatan pengabdian masyarakat yang dilakukan. Berdasarkan hasil evaluasi kegiatan pengabdian masyarakat yang dilakukan bahwa hampir semua (97\%) guru madrasah dalam penggunaan media pembelajaran secara daring secara signifikan terjadi peningkatan baik dari aspek pemahaman, pengetahuan dan keterampilan. Dapat dimpulkan kegiatan masayarakat yang dilakukan dapat meningkatkan kemampuan guru dalam penggunaan media pembelajaran secara daring.

This is an open access article under the CC-BY-SA license

\section{Pendahuluan}

Pandemi Covid-19 telah tersebar ke seluruh penjuru dunia termasuk di Indonesia, semua aktivitas yang manusia menjadi terbatas akibat pencegahan akan adanya penyebaran virus corona. Pemerintah telah melakukan berbagai ikhtiar untuk pencegahan terjadinya penyebaran virus corona. Pemerintah membuat berbagai kebijakan yang harus dipatuhi oleh masyarakat, salah satunnya guna mengurangi resiko terkena penularan virus Covid-19, dengan cara menjaga jarak atau physical distancing. Pemerintah juga menetapkan kebijakan pemberlakuan bekerja dan belajar dari rumah. Dengan demikian, maka menjalani aktivitas pekerjaan maupun pembelajaran dari rumah. 
Dengan demikian, maka kegiatan pembelajaran ditengah pandemi seperti ini tidak secara langsung atau bertatap muka, akan tetapi melalui kegiatan pembelajaran secara online (daring), hal ini sejalan dengan kebijakan pemerintah melalui surat edaran yang dikeluarkan oleh Kementrian Pendidikan dan Kebudayaan mengubah sistem pembelajaran tatap muka menjadi pembelajaran daring (dalam jaringan/online). Kebijakan yang dikeluarkan tersebut membuat pembelajaran yang dilakukan di sekolah maupun perguruan tinggi yang ada di Indonesia harus dilakukan secara daring untuk menyikapi pandemi Covid-19 yang mana telah terjadi di seluruh dunia.

Pembelajaran yang dilakukan secara daring ini, memiliki dampak tersendiri, biasanya pembelajaran dilakukan secara bertatap muka dalam ruangan yang dilengkapi fasilitas yang ada, kini harus dilakukan dengan jarak dan melalui media teknologi pembelajaran online. Menurut Yaumi (2018), bahwa media pembelajaran telah maju dan berkembang seiring dengan lahirnya revolusi komunikasi yang dimanfaatkan untuk tujuan pembelajaran selain media yang sudah ada sebelumnya seperti guru, buku teks dan papan tulis.

Pembelajaran daring merupakan pembelajaran yang dilakukan dengan cara memanfaat koneksi internet untuk mengakses dan menyalurkan materi belajar. Pelaksanaan pembelajaran secara daring lebih fleksibel dari segi ruang dan waktunya karena dapat diakses dimanapun dan kapanpun oleh siapapun dengan catatan bahwa telah tersedia layanan jaringan internet dengan baik. Menurut Asmariani (2016) bahwa untuk mencapai efektivitas pembelajaran dengan baik, diperlukan media pembelajaran yang tepat untuk menghubungkan keduanya secara bersamaan. Media pembelajaran merupakan bentuk alat komunikasi yang bersifat menyalurkan pesan atau bahan ajar dari pendidik kepada peserta didik sehingga dapat menstimulasi pikiran, minat, perasaan dan kemauan peserta didik dalam melakukan proses pembelajaran. Oleh karena itu, penggunaan media pembelajaran memiliki peran penting, karena dapat menstimulasi minat dan motivasi belajar siswa jika digunakan dengan benar, sehingga dapat tercapainya tujuan pembelajaran secara efektif dan efisien.

Perkembangan teknologi yang semakin canggih, menyediakan banyak sekali media pembelajaran daring yang dapat menunjang pembelajaran dengan jarak jauh. Kemendikbud terus mengembangkan dukungan melalui kerjasama dengan 12 mitra swasta memberikan layanan media pembelajaran gratis untuk dapat diakses oleh pendidik dan peserta didik. Adapun 12 media pembelajaran daring tersebut yaitu Google For Education, Microsoft office 365, Quipper School, Ruangguru, Rumah Belajar, Icando, IndonesiaX, Meja Kita, Kelas Pintar, Zenius, Cisco Webex, dan Sekolahmu (Adit, 2020). Diluar itu media pembelajaran yang juga bisa digunakan secara gratis adalah Zoom, WhatsApp, Google Classroom, Google Meeting, Edmodo, dan lainnya. Berbagai media pembelajaran yang ditawarkan tersebut tentunya tidak semuanya dapat digunakan oleh pendidik dan peserta didik. Oleh karena itu, pendidik harus mampu memilih media yang paling sesuai dengan situasi dan kondisi.

Pemilihan penggunaan media pembelajaran yang tepat tentunya akan berdampak pada pemahaman peserta didik ketika menerima materi ajar yang disampaikan oleh pendidik (Ekayani, 2017). Dengan penggunaan media pembelajaran yang tepat, tentunya kegiatan pembelajaran akan berjalan secara efektif dan efisien. Pengkajian mengenai pembelajaran Daring sudah dilakukan oleh beberapa akademisi dengan tema penggunaan media pembelajaran daring pada masa pandemi covid19 yang menunjukkan bahwa penggunaan media pembelajaran daring efektif dan pembelajaran akan lebih efektif apabila pendidik menerangkan materi melakukan belajar menggunakan video conference dengan memberikan pembelajaran yang ringkas namun mudah dipahami (Mustakim, 2020). Proses Pembelajaran dengan Media Daring pada Masa Pandemi COVID-19" menjadi alternatif bagi pendidik dalam melakukan proses belajar mengajar di tengah pandemi yang sedang berlangsung. Pendidik harus selektif memilih media yang akan digunakan sesuai dengan peruntukannya agar pembelajaran berjalan optimal.

Peningkatan kompetensi guru dalam ilmu pengetahuan dan teknologi merupakan suatu hal yang penting. Hal ini sejalan dengan pendapat Ansori $(2016,48)$ bahwa kewajiban manusia untuk berusaha memanfaatkan sumber dayanya bagi pengembangan ilmu dan teknologi dalam mengatasi 
kesukaran-kesukaran hidup. Dalam usaha memanfaatkan sumber daya manusia banyak yang cenderung berpikir bahwa ukuran spiritual Islam adalah suatu hal dan pengembangan ilmu adalah hal lain. Padahal dimensi spiritual sangat penting dalam pengembangan SDM. Namun faktanya kondisi di madrasah masih terdapat guru yang mengalami kesulitan dalam penggunaan media pembelajaran secara daring. Karena pada umumnya guru madrasah, khususnya pada madrasah swasta di daerah rata-rata berusia diatas 50 tahun, sehingga tidak terlalu familiar dengan media aplikasi berbasis IT yang dapat digunakan dalam pembelajaran daring. Oleh karena itu, penting dilakukan pendampingan terhadap guru madrasah untuk ditingkatkan kemampuannya dalam menggunakan dan memanfaatkan media pembelajaran yang berbasis IT untuk pembelajaran secara daring (online), dalam bentuk kegiatan pengabdian dosen dengan judul peningkatan kemampuan guru dalam penggunaan media pembelajaran secara daring di Kabupaten Pandeglang.

\section{Metode}

Pengabdian masyarakat berbasis Riset ini dilakukan dengan metode Service Learning. Metode ini dilakukan dengan cara memberikan pendampingan bagaimana pemanfaatan tekhnologi dalam media pembelajaran bagi guru pada masa pandemi. Dalam pengabdian masyarakat ini juga dilakukan penguatan bagi guru-guru yang sudah memahami penggunaan media namun masih mengalami berbagai kendala. Kegiatan pendampingan dan penguatan dalam pengabdian masyarakat ini memberikan layanan service learning bagi guru dalam berbagai kalangan sesuai dengan kemampuan guru. Fokus pengabdian masyarakat yang dilakukan ini berkaitan dengan pendampingan dan penguatan pelaksanaan pengabdian masyarakat bagi guru dalam peningkatan kemampuan guru dalam penggunaan media daring untuk pembelajaran. Kegiatan pengabdian pada masyarakat ini bertujuan meningkatkan strategi dan pelaksanaan peningkatan kemampuan guru dalam penggunaan media daring untuk pembelajaran. Oleh karena itu dilakukan pendampingan terhadap guru agar memiliki kemampuan yang baik bagaimana menggunakan dan memanfaatkan media daring yang berbasis teknologi informasi dalam melaksanakan kegiatan pembelajaran yang bermutu.

Kegiatan pengabdian ini dilakukan dengan konsep model IN-ON-IN, terdiri dari: Kegiatan pertama, In-l merupakan pertemuan awal untuk melakukan pembahasan penguasaan dan peningkatan keterampilan menggunakan media daring dalam pembelajaran, Kegiatan kedua, On the Job Learning merupakan praktek pembelajaran secara real yang dilakukan guru dengan menggunakan media daring pada kelas sesuai dengan jadwal masing-masing di satuan pendidikan, dan Pertemuan ketiga, In-2 merupakan pertemuan akhir untuk melakukan diseminasi atas pelaksanaan kegiatan On the Job Learning untuk evaluasi terhadap capaian, temuan, hambatan, dan tantangan yang dialami ketika melakukan praktek pembelajaran secara daring.

Sasaran pengabdian masyarakat ini adalah guru MTs di Kelompok Kerja Madrasah (KKM) MTs Negeri 1 Pandeglang, Kabupaten Pandeglang, Banten yang berjumlah 60 orang. Kegiatan ini melibatkan berbagai pihak, yaitu: (1) Kepala Seksi Pendidikan Madrasah Kementerian Agama Kabupaten Pandeglang, (2) Kepala MTsN l Pandeglang selaku Ketua KKM MTs Negeri 1 Pandeglang, (3) Dosen STKIP dan STAI Syekh Manshur Pandeglang sebanyak dua orang yang berperan sebagai narasumber (tutor) dalam pelatihan, (4) Guru MTs di lingkungan KKM MTs Negeri 1 Pandeglang sebanyak 60 orang sebagai peserta pelatihan, dan (5) panitia pelaksana kegiatan yang berperan dalam perencanaan, pelaksanaan, dan refleksi kegiatan.

\section{Hasil Pengabdian}

Pembelajaran secara daring yang dilakukan pendidik dengan memanfaatkan teknologi informasi dan komunikasi ditentukan oleh pendidik sebagai fasilitator untuk dapat memberikan kemudahan dalam pelaksanaan kegiatan pembelajaran. Oleh karena itu, pendidik perlu memiliki kemampuan dan keterampilan dalam menggunakan media daring dalam kegiatan pembelajaran. Sementara itu, tidak setiap guru memiliki kemampuan yang baik dalam menggunakan media daring yang berbasis teknologi informasi untuk melaksanakan kegiatan pembelajaran. Oleh karena itu dilakukan pendampingan terhadap guru agar memiliki kemampuan yang baik bagaimana menggunakan dan memanfaatkan media daring yang berbasis teknologi informasi dalam 
melaksanakan kegiatan pembelajaran yang bermutu. Kegiatan pendampingan ini dilakukan selama tiga kali dengan konsep pendampingan model IN-ON-IN, terdiri dari: Kegiatan pertama, In-1 merupakan pertemuan awal untuk melakukan pembahasan penguasaan dan peningkatan keterampilan menggunakan media daring dalam pembelajaran, Kegiatan kedua, On the Job Learning merupakan praktek pembelajaran secara real yang dilakukan guru dengan menggunakan media daring pada kelas sesuai dengan jadwal masing-masing di satuan pendidikan, dan Pertemuan ketiga, In-2 merupakan pertemuan akhir untuk melakukan diseminasi atas pelaksanaan kegiatan On the Job Learning untuk evaluasi terhadap capaian, temuan, hambatan, dan tantangan yang dialami ketika melakukan praktek pembelajaran secara daring. Dalam kegiatan pengabdian masyarakat ini untuk melihat keterukuran dari kegiatan pengabdian yang dilakukan juga dilakukan evaluasinya melalui kegiatan test kegiatan pengabdian masyarakat yang dilakukan untuk mengukur keefektifan dari kegiatan pengabdian masyarakat yang dilakukan.

Kegiatan pengabdian masyarakat yang dilakukan berbasis riset ini mengkombinasikan kegiatan pengabdian dengan kegiatan penelitian secara bersamaan untuk mengukur keterlaksanaan dari kegiatan pengabdian masyarakat yang dilakukan. Sebelum kegiatan pengabdian masyarakat dilakukan maka dilihat dulu kemampuan awal dari para guru yang akan diberikan pendampingan dan penguatan dalam penggunaan tekhnologi dalam media pembelajaran. Berdasarkan hasil kajian awal terhadap kegiatan pendampingan guru madrasah dalam peningkatan kemampuan penggunaan media daring untuk pembelajaran bagi guru madrasah di Kabupaten Pandeglang dapat dijelaskan hasilnya sebagaimana berikut:

Pertama, Pada kegiatan pertemuan awal (In-1), berdasarkan hasil pre-test tentang pemahaman guru madrasah tentang penggunaan media daring dalam pembelajaran hasilnya adalah sebagaimana terlihat dalam tabel berikut:

Tabel 1

Hasil Pre-Test Kemampuan Awal Guru Madrasah dalam Penggunaan Media Daring

\begin{tabular}{|c|c|c|c|c|l|}
\hline \multirow{2}{*}{ INTERVAL } & \multicolumn{2}{|c|}{ PRE-TEST } & \multicolumn{2}{|c|}{ POST-TEST } & \multirow{2}{*}{ KATEGORI } \\
\cline { 2 - 5 } & $\mathrm{f}$ & Persentase (\%) & $\mathrm{F}$ & Persentase (\%) & \\
\hline $00-20$ & 5 & 8 & 0 & 0 & Sangat rendah \\
\hline $21-40$ & 48 & 80 & 1 & 2 & Rendah \\
\hline $41-60$ & 4 & 7 & 1 & 2 & Cukup \\
\hline $61-80$ & 2 & 3 & 55 & 92 & Baik \\
\hline $81-100$ & 1 & 2 & 3 & 5 & Sangat Baik \\
\hline Jumlah & 60 & 100 & 60 & 100 & \\
\hline
\end{tabular}

Berdasarkan hasil pre-test sebagaimana tabel tersebut di atas, pemahaman guru madrasah tentang penggunaan media daring dalam pembelajaran sebagian besar atau pada umumnya masih rendah $(80 \%)$, bahkan jika digabungkan dengan kategori sangat rendah, maka terdapat $88 \%$ (sebagian besar) pemahaman guru madrasah tentang penggunaan media daring dalam pembelajaran masih relatif rendah.

Bertitik tolak dari hasil pre-test tersebut, maka kemudian dilakukan pendampingan terhadap guru agar memiliki pengetahuan, pemahaman dan keterampilan dalam penggunaan media daring untuk melakukan pembelajaran yang bermutu. Kegiatan pendampingan ini dilakukan yang diawali dengan kegiatan overview terhadap berbagai media daring yang dapat digunakan dalam kegiatan pembelajaran dengan segala kelebihan dan kekurangan serta cara penggunaan dan pemanfaatannya, kemudian dilanjutkan dengan kegiatan praktek dan simulasi penggunaan media daring. Sedangkan sesi terakhir kembali dilakukan evaluasi terhadap guru madrasah melalui post-test tentang pemahaman guru madrasah tentang penggunaan media daring dalam pembelajaran yang hasilnya sangat signifikan hampir semua guru (97\%) meningkat pemahaman, pengetahuan dan keterampilan 
dalam menggunakan media daring untuk kegiatan pembelajaran. Kemudian untuk lebih meyakinkan bahwa peningkatan pemahaman, pengetahuan dan keterampilan guru MTs dalam dalam menggunakan media daring untuk kegiatan pembelajaran setelah dilakukan pendampingan atau pelatihan melalui kegiatan pengabdian dosen bagi guru-guru madrasah di Pandeglang.

Kemampuan guru, baik dari aspek pemahaman, pengetahuan dan keterampilan dalam menggunakan media daring untuk kegiatan pembelajaran setelah dilakukan pendampingan mengalami peningkatan yang sangat signifikan. Selanjutnya efek perubahan (efek size) terhadap hasil pelaksanaan kegiatan pendampingan terdapat perubahan efek (efek size) yang besar (kuat) hasil pelaksanaan pendampingan terhadap pemahaman, pengetahuan dan keterampilan guru dalam menggunakan media daring untuk kegiatan pembelajaran.

Kedua, Pada kegiatan On the Job Learning, guru melakukan kegiatan praktek pembelajaran secara real yang dilakukan dengan menggunakan media daring pada kelas sesuai dengan jadwal masingmasing di satuan pendidikan. Dalam kegiatan ini, guru melakukan tiga tahap, yaitu (a) tahap persiapan, (b) tahap pelaksanaan, dan (c) tahap analisis-refleksi. Pada tahap persiapan, guru melakukan perencanaan kegiatan, dengan menyiapkan bahan ajar berupa bahan tayangan (slide) yang akan disajikan dalam media daring baik berupa teks, foto, video, dan bahan lainnya sebagai stimulus pembelajaran yang akan dilakukan, selanjutnya guru menetapkan media pembelajaran daring yang akan digunakan sesuai dengan kebutuhan dan kemudahan. Serta terakhir melakukan sosialisasi atau menyampaikan informasi kepada peserta didik tentang rencana kegiatan pembelajaran daring yang akan dilakukan melalui media Grup WA Kelas. Pada tahap pelaksanaan, guru melaksanakan kegiatan pembelajaran secara nyata (real teaching) sesuai dengan perencanaan yang disusun atau dipersiapkan. Kemudian tahap terakhir melakukan analisis dan refleksi terhadap kegiatan pelaksanaan yang telah dilakukan dalam bentuk catatan capaian dan temuan serta tindak lanjut untuk dilakukan perbaikan.

Ketiga, Pada kegiatan In-2 yang merupakan pertemuan akhir guru menyampaikan laporan hasil pelaksanaan real teaching menggunakan media daring sebagai bentuk diseminasi pelaksanaan kegiatan On the Job Learning untuk melihat kesuksesan atau kegagalan, evaluasi capaian, temuan, hambatan, dan tantangan yang dialami ketika melakukan praktek pembelajaran secara daring serta penyampaian alternatif penyelesaian masalah, sehingga hal ini menjadi pelajaran berharga bagi guru lain untuk mengambil hal positifnya (kesuksesannya) dan menghindari hal negatifnya (kekurangannya) agar tidak terjadi pada masing-masing guru ketika melakukan pembelajaran secara daring. Hasil praktek daring terlihat dalam tabel berikut di bawah ini:

Tabel 2

Hasil Diseminasi Guru Madrasah dalam Penggunaan Media Daring

\begin{tabular}{|l|c|c|l|}
\hline $\begin{array}{c}\text { Kriteria } \\
\text { Praktek Daring }\end{array}$ & f & Persentase (\%) & Keterangan \\
\hline Baik Sekali & 4 & 7 & Sukses \\
\hline Baik & 53 & 88 & Sukses \\
\hline Cukup & 3 & 5 & Kurang Sukses \\
\hline \multicolumn{1}{|c|}{ Jumlah } & 60 & 100 & \\
\hline
\end{tabular}

Berdasarkan tabel tersebut di atas, bahwa hasil diseminasi praktek pembelajaran daring yang dilakukan oleh guru adalah terdapat 57 orang guru atau sebagian besar guru (95\%) telah melaksanakan kegiatan pembelajaran daring dengan sukses dan bermutu dan sisanya 3 orang guru atau sedikit sekali (5\%) yang masih belum sukses dalam melakukan kegiatan pembelajaran secara daring, karena persoalan teknis berupa kendala jaringan internet yang kurang mendukung. Dari data di atas dapat dipahami kegiatan pengabdian masyarakat yang dilakukan memberikan dampak yang signifikan bagi guru madrasah dan juga memberikan manfaat bagi pemahaman guru mengenai media pembelajaran sekaligus pemanfaatannya dalam proses pembelajaran. 


\section{Pembahasan}

Berdasarkan kegiatan pengabdian masyarakat masyarakat berbasis riset dengan metode service learning di atas maka pembelajaran jarak jauh yang dilakukan melalui media daring berbasis teknologi informasi komunikasi, masih terdapat kendala yang dihadapi oleh pendidik maupun peserta didik. Namun teknologi sekarang ini menjadi keseharian hidup berdamping. Oleh karena itu, keberadaan teknologi informasi ini harus memberikan manfaat dan fungsi dalam memudahkan kegiatan pembelajaran bagi pendidik dan peserta didik dengan baik. Dilihat dari kepemilikan perangkat pendukung teknologi juga menjadi masalah tersendiri. Masih terdapat pendidik dan peserta didik memiliki perangkat teknologi yang kurang dimanfaatkan sebagai fasilitas penunjang dari kegiatan belajar mengajar secara daring. Hal ini sejalan dengan hasil penelitian Aprilia (2020) bahwa fasilitas pendukung yang dimiliki oleh pendidik dan atau peserta didik baik berupa laptop maupun gadget kurang memadai dan kurang optimal untuk digunakan dalam melakukan kegiatan pembelajaran. Maka kegiatan pendampingan dan penguatan dalam penggunaan media pembelajaran secara daring sangat bermanfaat bagi guru untuk mempermudah mereka dalam melaksanakan proses pembelajaran.

Pada saat pembelajaran daring selain banyak peserta didik yang mengeluhkan banyaknya tugas yang diberikan oleh guru adalah kesulitan akses internet, hal tersebut menjadi penghambat peserta didik dalam mengikuti proses pembelajaran maupun mengumpulkan tugas yang diberikan oleh guru. Jaringan internet menjadi hal yang paling penting dalam proses pembelajaran yang dilakukan secara daring. Dengan belum meratanya jaringan internet di Indonesia, tentu menjadi hambatan tersendiri bagi sebagian kalangan yang tempat tinggalnya di daerah sulit jaringan dan yang berada di pelosok desa.

Permasalahan lain juga muncul dalam kegiatan pembelajaran pada masa daring yang terungkat dalam kegiatan pengabdian masyarakat berbasis riset ini adalah pendidik kurang kreatif dan inovatif dalam pembelajaran daring, sehingga peserta didik mengalami kejenuhan dan merasa bosan dalam mengikuti pembelajaran daring yang diberikan oleh pendidik. Berbagai platform yang dapat digunakan dalam pembelajaran secara daring ini sebagai penunjang proses kegiatan belajar mengajar, yaitu google classroom, elearning, edmodo, zoom, google meet, whatsApp dan lain sebagainya untuk menjadi penunjang agar proses pembelajaran berjalan dengan baik sekalipun dalam masa pandemi seperti sekarang ini. Namun, terdapat beberapa platform yang cenderung ringan dan mudah ketika digunakan dalam pembelajaran secara daring ini, diantaranya adalah WAG dan google classroom. Hal ini sejalan dengan hasil wawancara yang dilakukan juga dalam kegiatan pengabdian masyarakat ini yang menunjukkan bahwa, sebagian besar pendidik menggunakan teknologi media pembelajaran dengan platform WAG dan juga google classroom, dengan alasan karena keduanya sangat mudah digunakan. Fungsi kedua platform tersebut tidak jauh berbeda, dapat digunakan untuk mengirim gambar, video, dokumen dan lain sebagainya. Platform ini juga memudahkan pendidik dalam memberikan materi kepada peserta didik agar dapat dengan mudah dimengerti peserta didik. Dalam hal penyampaian materi, pendidik juga harus dapat menyajikan materi yang akan disampaikan dengan kreatif dan variatif sehingga tidak membosankan peserta didik. Untuk membuat video pembelajaran dan materi supaya lebih menarik, pendidik dapat menggunakan berbagai aplikasi penunjang yang mudah digunakan. Materi atau video pembelajaran yang dibuat dapat disampaikan oleh pendidik melalui platform seperti WAG dan google classroom. Hal ini sejalan dengan pendapat yang dikemukakan oleh Kosim $(2015,125)$ bahawa pengembangan pembelajaran diarahkan pada pendekatan pembelajaran. mengapa harus pada pendekatan pembelajarannya? sebab pendekatan pembelajaran merupakan proses memilih dan menyusun kegiatan pembelajaran dalam suatu unit pembelajaran, seperti urutan , sifat materi, ruang lingkup materi metode, dan media yang paling sesuai untuk mencapai kompetensi pembelajaran.

Banyaknya platform pembelajaran yang tersedia, maka setiap pendidik tentu saja bebas memilih menggunakan platform yang sesuai dengan kebutuhan dari setiap peserta didiknya. Namun 
tentu saja setiap platform yang digunakan tentu memiliki kendala yang berbeda-beda. Oleh karena itu, perlu secara cermat menentukan dan merancang serta melakukan persiapan sebelum melakukan kegiatan pembelajaran secara daring. Hal ini sejalan dengan pendapat Briliannur (2020) bahwa persiapan sebelum memberikan layanan belajar merupakan salah satu faktor penentu dalam keberhasilan belajar, terutama pada online learning di mana adanya jarak antara pembelajar dan pengajar. Ini menjadi perhatian dan gaya baru yang dilaksanakan dalam proses pembelajaran saat ini. Efektivitas kegiatan pendampuingan dan penguatan pembelajaran dengan sistem daring tersusun dari faktor pendidik dan peserta didik, dimana pendidik memberikan pembelajaran kepada peserta didik dan peserta didik dapat juga berbagi dengan sesama peserta didik.

Dalam kegiatan pengabdian berbasis riset ini dapat juga dipahami beberapa hal penting yang perlu diperhatikan adalah bahwa kesiapan pendidik dan peserta didik dalam pelaksanaan pembelajaran secara daring adalah tolak ukur tingkat keberhasilan dalam proses penyampaian dan penyerapan materi pembelajaran. Sehingga pesan edukatif dari pendidik maupun orangtua sangat penting untuk melakukan dalam pembelajaran daring agar setiap konten yang disampaikan dapat tepat sasaran dan diterima dengan baik oleh peserta didik. Sehingga keterbukaan pendidik dalam menerima berbagai saran dan masukan dari peserta didik dan orang tua sangat memicu semangat belajar peserta didik. Oleh karena itu, komunikasi harus tetap terjalin secara baik dari pendidik dan orang tua dalam kegiatan belajar di rumah oleh peserta didik sebagai objek utama pembelajaran daring yang dilakukan. Maka dalam kegiatan masyarakat ini, memberikan pendampingan dan penguatan penggunaan media pembelajaran secara daring agar guru lebih memahami dan lebih dapat untuk mengaplikasikan media pembelajaran dalam kegiatan proses pembelajaran secara daring pada masa pandemi.

\section{Kesimpulan}

Kegiatan pengabdian masyarakat berbasis riset yang dilakukan dapat disimpulkan sebagai berikut: Pertama, Kemampuan guru madrasah dalam penggunaan media pembelajaran secara daring adalah hampir semua guru secara signifikan meningkat pemahaman, pengetahuan dan keterampilan dalam menggunakan media daring untuk kegiatan pembelajaran. Kemampuan guru dalam pemahaman, pengetahuan dan keterampilan dalam menggunakan media daring untuk kegiatan pembelajaran setelah dilakukan pendampingan mengalami peningkatan yang sangat signifikan. Adapun efek perubahan (efek size) terhadap hasil pelaksanaan kegiatan pendampingan setelah dianalisis terdapat perubahan efek (efek size) yang besar sebagai efek hasil pelaksanaan pendampingan yang dilakukan terhadap guru baik dari aspek pemahaman, pengetahuan dan keterampilan guru dalam menggunakan media daring untuk kegiatan pembelajaran. Kedua, Kegiatan On the Job Learning, dilakukan berupa praktek pembelajaran secara real melalui media daring pada kelas masing-masing di satuan pendidikan dengan tiga tahap, yaitu (a) tahap persiapan, (b) tahap pelaksanaan, dan (c) tahap analisis-refleksi. Tahap persiapan, guru melakukan perencanaan kegiatan, dengan menyiapkan bahan ajar yang akan disajikan serta penyampaian informasi kepada peserta didik tentang rencana kegiatan pembelajaran yang akan dilakukan melalui media Grup WA. Tahap pelaksanaan, guru melaksanakan kegiatan pembelajaran secara nyata sesuai dengan perencanaan yang disusun, dilanjutkan dengan analisis dan refleksi serta tindak lanjut perbaikan. Sedangkan yang Ketiga, Kegiatan In-2 merupakan diseminasi pelaksanaan kegiatan On the Job Learning untuk melihat kesuksesan atau kegagalan, evaluasi capaian, temuan, hambatan, dan tantangan yang dialami ketika melakukan praktek pembelajaran secara daring serta penyampaian alternatif penyelesaian masalah. Adapun secara umum hasil diseminasi kegiatan pengabdian masyarakat yang dilakukan setelah pendampingan dan penguatan pemanfaatan penggunaan media secara daring dengan sukses dan bermutu dan sisanya sedikit sekali (5\%) guru yang masih belum sukses dalam melakukan kegiatan pembelajaran secara daring, karena persoalan teknis berupa kendala jaringan internet yang kurang mendukung. Hal ini dapat disimpulkan bahwa kegiatan pengabdian masyarakat berbasis riset dengan metode service learning bagi guru-guru madrasah di Kabupaten Pandeglang memberikan efek yang positif dan manfaat yang besar bagi guru dalam penggunaan media secara daring. 


\section{Daftar Pustaka}

Adit, A. (2020). 12 Aplikasi Pembelajaran Daring Kerjasama Kemendikbud. https://edukasi.kompas.com/read/2020/03/22/123204571/12-aplikasi-pembelajaran-daringkerjasama-kemendikbud-gratis?page=all

Anshori, A. H. (2017). Pentingnya Manajemen Berbasis Sekolah/Madrasah Dalam Kepemimpinan Sekolah/Madrasah Efektif. Tarbawi: Jurnal Keilmuan Manajemen Pendidikan, 2(01), 23-38.

Ansori, A. H. (2009). Pengaruh Kecerdasan Intelektual, Strategi Metakognitif dan Pengetahuan Awal Terhadap hasil Belajar Matematika. Jakarta: Universitas Negeri Jakarta (Tesis).

Ansori, A. H. (2016). Strategi Peningkatan Sumber Daya Manusia dalam Pendidikan Islam. Qathruna, 2(02), 19-56.

Ansori, A. H. (2017). Statistika untuk Penelitian. STAISMAN Press.

Ansori, A. H. (2021). Penelitian Tindakan Sekolah Panduan Praktis bagi Kepala Sekolah dan Pengawas Sekolah. STAISMAN Press.

Aprilia, Dewi Astuti, D. P. (2020). Efektivitas Penggunaan Media Belajar Dengan Sistem Daring Ditengah Pandemi Covid-19. Malang: Fakultas Ilmu Pendidikan Universitas Negeri Malang.

Asmariani, A. (2016). Konsep Media Pembelajaran Paud. Al-Afkar: Jurnal Keislaman \& Peradaban. https://doi.org/10.28944/afkar.v5il.108

Briliannur, Dwi C, dkk. (2020). Analisis Pembelajaran Online di Masa Pandemi Covid-19, Jurnal Pendidikan Guru Sekolah Dasar, 2(1).

Ekayani, P. (2017). Pentingnya Penggunaan Media. Jurnal Fakultas Ilmu Pendidikan Universitas Pendidikan Ganesha Singaraja, March. https://www.researchgate.net/publication/315105651.

Kosim, N. (2015). Pengembangan dan Aplikasi Pembelajaran PAI di SD. Qathrunâ, 2(02), 121-142.

Mustakim. (2020). Efektivitas Pembelajaran Daring Menggunakan Media Online Selama Pandemi Covid-19 Pada Mata Pelajaran Matematika. Al-Asma: Journal of Islamic Education. https://doi.org/10.24252/asma.v2il.13646 